\title{
DNA チップの材料と成形技術
}

\section{1.はじめに}

（1）DNA チップの定義

DNA チップとは，DNA マイクロアレイとも呼ば れ，一本鎖 DNA を基板上に複数固定したデバイスで ある。

(2) DNA チップの原理

DNA は 4 種類の核酸塩基で構成されており，それ ぞれ特定の核酸塩基と，すなわちアデニンはチミンと， グアニンはシトシンと, 相補的に水素結合する. 従っ て，あらかじめ検出したい DNA（ターゲット）の塩 基配列と相補的な塩基配列を持つ一本鎖 DNA（プ ローブ)を基板上に固定しておけば, 検体中にターゲッ 卜が存在した場合，基板上にハイブリットを形成する (ハイブリダイゼーション). DNA チップはこの原理 を利用し，複数の DNA を同時並行的に検出する（図 1).

(3) DNA チップの用途

DNA チップにて遺伝子の型や発現を解析すること により, 病気の症状を詳しく理解したり, 病気のかか りやすさ，薬の効果や副作用を予測したりできる。 た，病原体やウィルスの同定にも利用できる.
DNA チップの市場は，現状，ゲノムやトランスク リプトーム解析などの基礎研究用や創薬研究用がほと んどであるが，欧米にて，2004 年にチトクローム P 450 の遺伝子の型を判別し, 薬剤の感受性を調べる DNA チップが，2007 年に遺伝子の発現を解析し，乳 がんの予後予測をする DNA チップが診断薬として, 米国食品医薬品局（FDA）で認可を受け上市され, また，国内では子宮頸がんの原因となるヒトパピロー マウイルス（HPV）の型を判別する DNA チップが上 市されるなど，診断検査用の市場も広がり始めている.

\section{2. 板状タイプの DNA チップ}

DNA チップは，主に，スライドガラス型の板状タイプ であり，あらかじめ調製もしくは合成したプローブを基板 にプリントする方法（プリント法）と，プローブを基板上 で合成する方法（オンサイト合成法）の 2 種類の製造方法 にて大別できる．前者はスタンフォード型と呼ばれ，後者 の代表はアフィンメトリクス型であり，その詳細について 以下に説明する (図 2).

(1) 板状タイプ DNA チップの種類

(1)スタンフォード型

基板上に生物由来の相補的 DNA（cDNA）をポリ

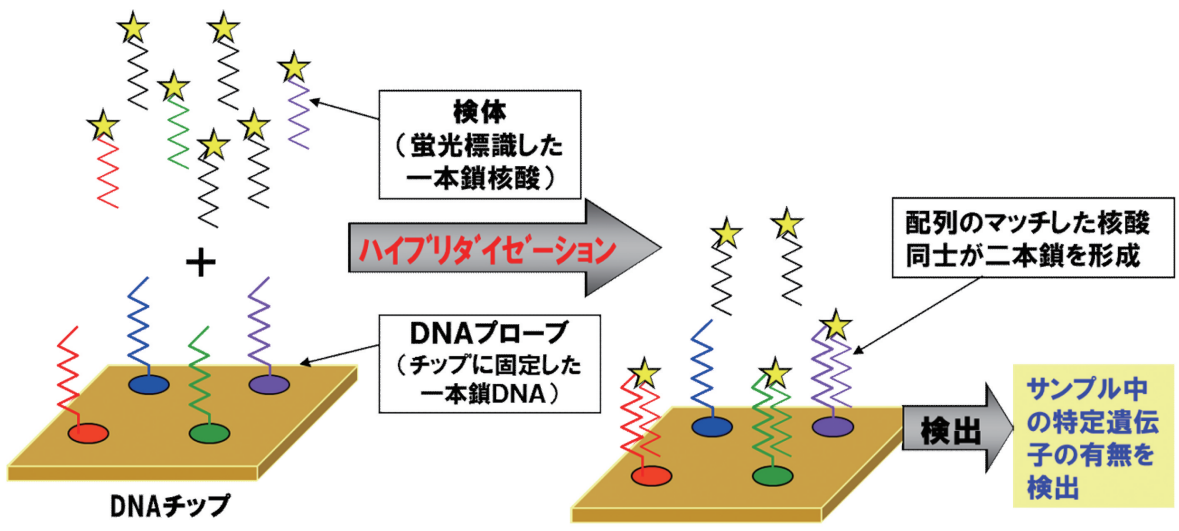

図 1 DNA チップの原理

\footnotetext{
* Kusaka, Koji

三菱レイヨン(侏) 横浜研究所 バイオデバイス研究 $\mathrm{G}$

横浜市鶴見区大黒町 10-1（开230-0053）

kusaka_ko@mrc.co.jp

2013.11. 12 受理
} 


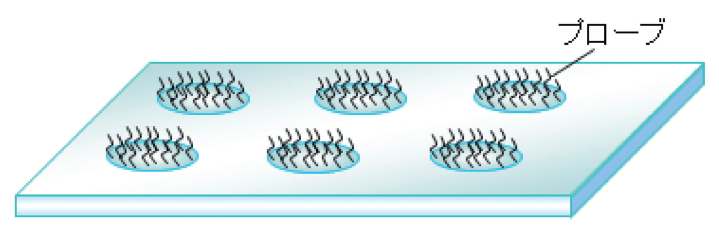

図 2 板状タイプ DNA チップの模式図

メラーゼ連鎖反応（PCR）増幅してプローブとしてプ リントしたタイプは, cDNA が静電的に基板表面に 張り付いており，積極的に固定化されていないため, ハイブリダイゼーション後の洗浄にて流れ出してしま う可能性が高く，定量性に問題がある.

このために，アミノ修飾もしくはチオール修飾した 25〜60 塩基のオリゴ DNA をプローブとして, 表面 修飾した基板に積極的に固定したタイプが主流となっ ている，プリント方法には，ピン方式，インクジェッ ト方式, バブルジェット方式, キャピラリー方式など がある。

スタンフォード型の欠点は, プローブの絶対量のば らつきと固定化率の低さによるスポット間のばらつき と液の偏りによるスポット内のばらつきである。また， 修飾した DNA や修飾タイプの基板を用いる場合はコ ストが高くなる。

(2)アフィンメトリクス型（GeneChip $\mathrm{R})$

光感受性保護基と半導体回路の製造技術である光り ソグラフィ技術及び固相反応技術を用いて製造する。

フォトマスクを用いて基板上の任意の場所に光を照 射し光感受性保護基を外して，20〜25 塩基の任意の オリゴ DNA を合成しプローブとするタイプである。

このタイプはプローブがプリント法に比して高密度 に形成できるが，基本的にはプリント法と同じくチッ プを 1 枚ずつ作製することになるため，チップ間の データの再現性を保証することが難しい.

また, 光感受性保護基を有した塩基試薬を用いるた め, 合成されるオリゴ DNAの長さが短く, 正常なプ ローブの比率が低いことやフォトマスクのずれにより プローブ領域が曖昧となる可能性があることなどが検 出精度に影響を与える，加えて，高額なフォトマスク を多数必要とするため，コストが高くなる.

検出精度の向上のために，1遺伝子あたり複数のプ ローブを用いて測定が行われている.

(3)その他のオンサイト合成チップ

イ。ニンブルジェン型（マスクレス製造法）

アフィンメトリクス型同様に光媒介化学合成技術 を応用しているが，フォトマスクを使用せず，コン ピュターでマイクロミラーを精密に制御することに より，基板上の任意の場所に光を照射し光感受性保 護基を外してプローブを合成する。

フォトマスクを必要としないタイプであるため,

柔軟な製造ができ, コスト低減が可能であるが,フォ トマスクほど高密度はできない.

ロ.アジレント型（インクジェット合成法）

DNA 合成に一般的に用いるアミダイト試薬を用 いた任意のオリゴ DNA の試薬溶液をインクジェッ
ト技術により基板上の任意の場所にスポットし，そ の場にてプローブを合成するタイプである.

合成収率が高く，60 塩基程度までオリゴ DNA を長くでき，1遺伝子あたり 1 プローブで検出でき るが，スポットする液量のばらつきが検出精度に影 響を与える。

ハ. その他のオンサイト合成チップ

半導体回路の製造技術を用いて，基板上に微小電 極を設け，任意の電極に電気を流すことでその電極 の場所にプローブを合成するタイプやポリマーで塩 基合成サイトをマスクすることで ACGT の塩基の 選択を行うポリマーマスキング法でプローブを合成 するタイプがある。

（2）板状タイプ DNA チップの基板材料

(2)一般的な素材（シリコン，ガラス)

DNA チップの検出技術には，ターゲットを蛍光物 質で標識する蛍光検出法が最も広く用いられている. このため，DNA チップの基板には，自己蛍光が少な い素材が求められる.

また，光学系には多く用いられる共焦点レーザーは， 焦点深度が浅いので，基板以外の部位からの蛍光や反 射光を除去ができ， $\mathrm{S} / \mathrm{N}$ 比が高い画像データが得ら れるが，反面，基板の平滑性やステージのゆがみの影 響を受けやすい. このため, 基板には高い平滑性が求 められる. 加えて, チップ上での反応中の加温工程 $(60$ 〜 70 C) により変形しないことが求められる.

これらの理由により, DNA チップの基板の素材に は, ガラスや半導体基板に用いられるシリコンが用い られるが，現状ではガラスが主流となっている。これ はプローブの固定化のために基板は化学的な表面処理 がなされることが多く，ガラスは様々な溶媒に対して 耐性があり，また，安価に処理できるためである。

(2)プラスチック

ガラスは, 加工性が悪く, DNA チップシステムの 自動化に有用なマイクロ流路加工に対しても加工費用 の面も含め大量生産性に欠ける。また，破損しやすく， 診断検査へ実用された場合に作業者への二次感染など のリスクが懸念される. 加えて, 生産コストの低減が 難しい. このため, DNA チップの沉用化, 検査用途 への実用化に向けて，プラスチックが基板の素材とし て期待される。

DNA チップに適したプラスチック素材は, 自己蛍 光が少なく, 透過式検出器のためには透明性が高く, 平滑性を高めるために成形性が高い必要がある.

加えて, 耐熱性, 耐薬品性が求められる。（自己蛍光 についてはガラスに比して劣るが, 現在実用できる無 蛍光タイプのプラスチックが上市されている.）

シクロポリオレフィンコポリマー樹脂は，これらの 要件を満たしている. また, ポリメタクリル酸メチル 樹脂は, 加工性や透明性が高いためマイクロ流路加工 を用いるチップなどに使用されることが多い.

理化学器具に広く用いられるプラスチックでは, ポ リスチレン樹脂は, 加工性や透明性が優れているが, 自己蛍光が高く, 耐熱性, 耐薬品性が低いことが課題 
となる。また，ポリプロピレン樹脂は，耐熱性，耐薬 品は高いが, 透明性, 加工性が低い.

(3)特殊表面処理をしたプラスチック

ハイブリダイゼーション由来のシグナル強度とバッ クグラウンドの差 $(\mathrm{S} / \mathrm{N}$ 比) が十分にとれない場合, DNA チップの検出感度が低くなる．このため，DNA チップの検出感度を上げるには，プローブのターゲッ 卜に対する捕捉機能すなわち選択的特異性を高くする ことはもとより, ターゲットが基板へ非特異的に吸着 することにより発生するノイズを抑制することが必要 である。

住友ベークライトは, 光架橋超親水性ポリマーによ りプラスチック表面を高密度に水酸化し, 生体分子の 非特異吸着を効果的に抑制したポリマー層を形成する 表面処理技術を開発した。

プローブを固定するためにアミノ基と反応する活性 エステル基を導入した光架橋超親水性ポリマーを用い て表面を処理した生体分子低吸着性のプラスチック素 材を DNA チップの基板に用いることにより， S/ $\mathrm{N}$ 比 が高い検出が可能となるとともに，基板上での酵素活 性が高くなることを利用して検出時間を短縮すること も可能となる.

また，基板上でのアビジン・ビオチン反応後の BCIPによる呈色反応が効率よく進むため, シグナル の可視化が可能となる.

(4)その他の素材

イ、ポリジメチルシロキサン（PDMS）

PDMS はシリコンゴムの一種である．微細加工 が可能であり，マイクロ流体チップなどがガラスや プラスチックに比して容易に作製できる．また，無 色透明であり可視領域の吸収が少なく，自己蛍光は ほとんどないため，蛍光検出に用いることができる。 加えて，生体適合性材料であるので DNA チップに 適した素材である。

現状ではガラスと同様に大量生産性に欠けるため, 実用化においてはプラスチックの方が有利である.

ロ.ダイヤモンド

ダイヤモンドは，炭素系材料の中では炭素原子が 最も高密度に配列した結晶構造を有している。その ため，表面の $\mathrm{C}-\mathrm{H}$ 結合に官能基を修飾することに より，他の素材より多くのプローブを，結合力の強 い共有結合で固定することができる.

また，プローブと基板を短いリンカーもしくはリ ンカーなしで結合することができるため，基板表面 とプローブを近づけ，その化学的，電気的な相互作 用をハイブリダーゼーションに積極的に利用するこ とができる。

半導体基板に用いるシリコン基板の表面にダイヤ モンドを製膜し，DNA を共有結合した基板やダイ ヤモンドの代わりにダイヤモンドライクカーボン （DLC）をシリコン基板に製膜した基板を用いた DNA チップが開発されており，低価格かつ迅速な SNPs 検出（遺伝子の 1 塩基の違いを判定する）を 実現している.

\section{3. 異型タイプの DNA チップ}

板状夕イプの DNA チップでは, 基板表面上でのハイブ リダイゼーションにおいて，DNA 分子鎖の立体障害や分 子間静電気相互作用，基板表面の荷電などの影響により反 応が阻害される.

このため，解析対象とプローブの相互作用を多くするこ とを目的として，基板の表面積や固定化するプローブ密度 を高くした異形タイプの DNA チップが開発された。

異型タイプの DNA チップには，微細孔を有する無機材 料を基板として用いたタイプ，基板表面を凹凸に形成した 「柱状構造型」，中空纎維内に充填したハイドロゲルに，プ ローブを固定した「中空繊維型」，ビーズ上の基材にプロー ブを固定した「ビーズアレイタイプ」，1本の糸にプロー ブを物理的に固定し，これを円筒状のプラスチック容器に 巻きつけた「糸巻きタイプ」などがある，その他，ターゲッ トへの蛍光標識がいらない電気化学的検出型がある.

以下にいくつかの異型タイプの DNA チップの詳細につ いて説明する.

(1) 電気化学検出型（東芝）

絶縁された基板上に形成された電極表面にプローブ を固定したDNA チップである.

プローブとターゲットがハイブリダイゼーションし た後に投入した挿入剂が 2 本鎖となった DNAのみに 結合する.この状態に電圧をかけることにより挿入剂 が酸化し電極に電流が流れるが，この電流を測定し ターゲットを検出する（図 3).

蛍光検出方式と比ベターゲットへの蛍光標識工程が 必要なく低コストにて, 高感度な検出が期待できる.

また, 装置の小型化, 自動化に適しており, デー夕解 析も容易である.

その他， 2 本鎖 DNA 形成による静電気容量の増加 を，基板自体にシーモス（CMOS）半導体回路を組み 込んで直接的に検出する技術などがある.

(2) ビーズアレイ

プローブを固定したビーズをマイクロウェルが形成 された基板に，ランダムにばらまき，穴に自己配列さ せた DNA チップがイルミナから市販されている，基 板には，シリコン基板のほか，約 5 万の光ファイバー 繊維束を利用したものがある.本方法では, 個々のビー ズの位置は固定されるが，それに固定されたプローブ の配列はわからないため, デコーディングという工程 が必要となる。

その他，プローブを固定したビーズをサンプル チューブに入れてハイブリダイゼーションし，あらか じめビーズに付与した蛍光色素の含有量でプローブ配 列を見分ける方式（ルミネックス）やプローブを固定

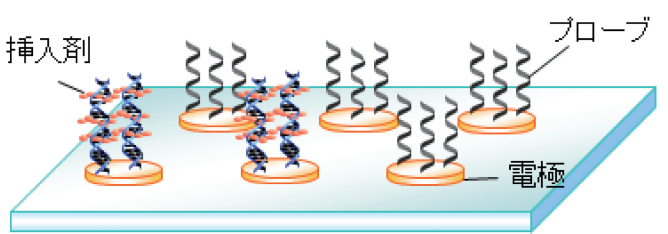

図 3 電気化学検出型 DNA チップの模式図 
したビーズをキャピラリーの中に詰めて並べる方式が ある。

（3）柱状構造型（東レ「3 D-GENER」）

加工性が良く，自己蛍光が少ないプラスチックの基 板表面に直径, 高さとも数十ミクロンから数百ミクロ ンの凹凸構造（柱状構造）を形成し，その柱の上にプ ローブを固定化したDNA チップである（図 4).

プローブのスポット形状が安定化されること，柱状 構造の上端面のナノレベル設計によりハイブリダイ ゼーション効率が最も良い密度でのプローブの固定及 び基板表面への DNAの非特異性吸着抑制ができる （ノイズが低減できる）ことにより，高精度の検出が 期待できる.

また，柱と柱の間に直径数十〜数百 $\mu \mathrm{m}$ のビーズ を配置し，ハイブリダイゼーション時にビーズよる攪 拌を行うことで，プローブに影響を与えることなく，

ターゲットの拡散を向上させ反応を促進させることが 可能となり，高感度化が期待できる.

（4）中空繊維型（三菱レイヨン「ジェノパール $\mathrm{R} 」)$

(1)「ジェノパール $\mathrm{R} 」 の$ 特長

当社 DNA チップは，黒色の基板に配置された貫通 孔にプローブがゲルを介して三次元に固定されている (図 5).

プローブがフレキシブルな状態にあるためプローブ の利用効率が高くなることや, DNA の 2 本鎖形成の ための十分なスペースが提供できること，また，大容 積であるため板状夕イプより多くのプローブを固定で きることにより, 高い感度と拾いダイナミックレンジ の検出が可能である. また, 光を通さない黒色の基板 に貫通孔を有しているため, 透過光によるスポット位 置特定を迅速かつ容易にできる.加えて, 製造からユー ザー使用に至るまでのすべての工程でプローブが ウェットな環境に存在するため, 初期設計通りの性能 を提供することができる。

(2)「ジェノパール $\mathrm{R} 」$ の特長

当社 DNA チップの三次元構造は, 繊維技術を利用 したその独特な製造技術により形成される，以下に製 造方法を説明する（図 6).

イ. 内径 $100 \mu \mathrm{m} \sim 200 \mu \mathrm{m}$ の中空繊維を三次元に配

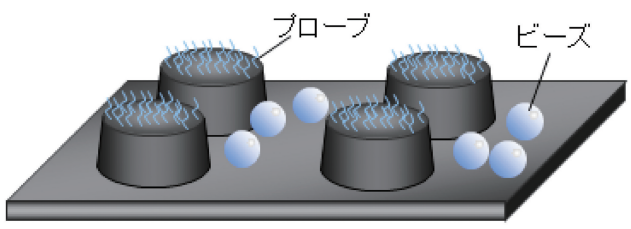

図 4 柱状構造型 DNA チップの模式図
列し，ウレタン樹脂で固定した中空繊維配列体を 作製する。(中空緎維用樹脂，ウレタン樹脂は， 自己蛍光を抑制するためにカーボンブラックを分 散する.)

ロ. 次に配列された中空繊維の中空内部にプローブと これを担持するためのハイドロゲルのモノマーの 混合液を充填し，共重合する。

ハ.その後, ハイドロゲルが充填した中空繊維配列体 を数百 $\mu \mathrm{m}$ 間隔でスライスする.

この製造方法を「金太郎飴方式」と呼んでいるが, 同品質の DNA チップを安定的に，大量に製造できる とともに，搭載したプローブやゲルの状態などを抜取 検査することにより品質保証が可能となる.

この製造方法は，低価格で再現性ある DNA チップ を工業的に生産できる方法である.

現在，1個の中空繊維配列体から得られるDNA チップの枚数は約 300 枚であるが，中空繊維配列体の 長さを長くしたり，DNAチップの厚みを薄くしたり することなどにより数千枚単位まで可能である。また， 共重合プロセスをコントロールすることにより，用途 や目的に最適なプローブ密度とすることができ，広範 囲な用途への展開が期待できる.

\section{4．おわりに：DNA チップの今後の課題}

国内の研究用の DNA チップ市場（解析支援装置市場） は, 次世代シーケンサーの登場によりユーザー数が減少し つつあり，また，診断検査用は臨床検査にてほとんど用い られていないことから，2013 年 26 億円から 2018 年 20 億 円と減少すると予測されている.

一方, 遺伝子検査用体外診断薬の世界市場は, 2010 年
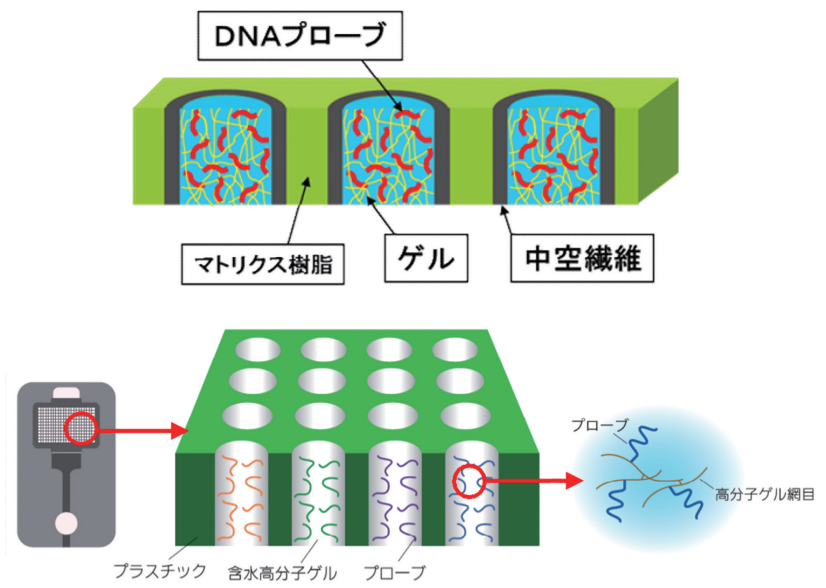

(A)全体像
(C)プロープの樣子

図 5 「ジェノパールR」の構造

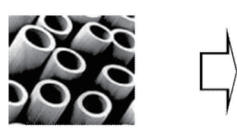

中空繊維

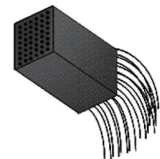

中空繊維配列体 ゲル重合（DNA固定）
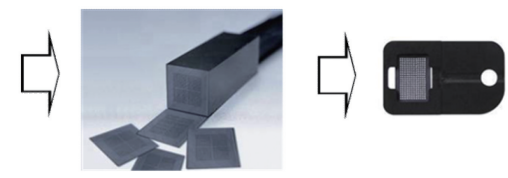

スライス・薄片体ジェノパール

図 6 「ジェノパール囚」の製造方法 
度に 1, 360 億円（内訳は感染症遺伝子検査が 1,255 億円， がん遺伝子検査が 105 億円である.）であるが，2020 年に は 2,000 億円近くに達すると予測されている。（内訳は感 染症遺伝子検査が 1,690 億円，がん遺伝子検査が 300 億円 である.）因みに，国内の現状の遺伝子検査用体外診断薬 の市場規模は約 60 億円である.

現在, 遺伝子検査技術においては, リアルタイム PCR が最も多く利用されており産業として成り立っている。一 方, DNA チップは, 診断薬の開発があまり進んでおらず, 研究用が主流であり, 産業化には至っていない。

遺伝子解析技術の進展に伴い, 疾患に関する遺伝子変異 や多型が逐次発見されてきており，テーラーメード医療が 現実化してきた. 今後, 遺伝子検査用体外診断薬の開発が 更に活発になると思われるが，次世代シーケンサー用の診 断薬の開発動向にも注目しながら，DNA チップを検査市 場において産業として発展させるために，ハードウェアの 開発のみならず，ターゲットへの標識技術やハイブリダイ セーション技術などのソフトウェアの改良も踏まえ以下の 課題を解決していかねばならない.

1. 検出の精度及び信頼性, 再現性の更なる向上

2. 解析時間の短縮
ハイスループット (多検体処理) 技術の開発，反応 時間の短縮など

3 . 利用コストの低減

大量生産可能なチップ(低価格化)の開発やターゲッ 卜に標識をしない検出技術の開発など

4. DNA チップシステムの自動化

ベッドサイドでの解析可能で，だれでも簡単に使え るシステムの開発

1) マイクロアレイ・バイオチップの最新技術,

監修：伊藤嘉浩，シーエムシー出版 (2007)

2) DNA チップ活用テクノロジーと応用

監修：久原 哲，シーエムシー出版 (2006)

3 ) 個別化医療の普及と世界の遺伝子検査ビジネスの今後 の方向性，シード・プラニング (2012)

4) 東芝ホームページ DNA チップの原理 http://www3.toshiba.co.jp/ddc/dnachip/

5 ) 第 19 回（2005 年）独創性を拓く先端技術大賞 産経新聞社賞受賞論文 東レ(株)先端融合研究所ナノバイオグループ

\section{学位取得者の紹介}

\section{氏 名：加藤 真理子}

学位取得時期：2013 年 9 月

学位取得機関：山形大学 博士 (工学)

指 導 教 官: 伊藤 浩志 教授

論 文 題 目：フルオレン含有ポリエステルの射出成形に おける基礎的研究

所属：大阪ガスケミカル株式会社 ファイン材料 事業部 ファイン材料開発センター

会 社 住 所：大阪市此花区酉島 5-11-61（†554-0051）

連 絡 先：kato@ogc.co.jp

論文要 旨:

フルオレン系ポリエステル（FBP）は非晶性であり，射 出成形可能な透明高分子である.FBP は(1)射出成形した 成形物の屈折率が 1.6 以上とポリカーボネート (PC) に 比べて大きい, (2)成形物の複屈折が非常に小さい, (3)アッ ベ数が PC に比べて小さい, という特徴を持っており, 新 しい光学用プラスチックとして注目されている．本論文で は, 光学材料としての各種特性のほか, 射出成形時の挙動 や添加剤, 金型表面加工の離型性への影響について考察を 行い, さらに環境による変化も含めて, 光学レンズとして の性能検証を目的とした. 最初に, フルオレン構造を特徴 とする 3 種類の FBP と, 光学材料として代表的な PCの 比較を光学特性, 流動特性, 成形品の特徵の観点から比較 したＦFP同士で比較した場合，フルオレン環を含むカ ルド構造部分の複屈折はその構造の特異さから打ち消され る. その為, 光学特性の違いはフルオレン環と共重合する 部分構造により決定される事があきらかになった。FBP と PC を比較した場合, PC は Tg を超えて変化をする場
合に, FBP に比べて流動性, 光学特性共に大きく変化す

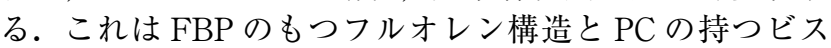
フェノール構造の違いに起因すると考えられる。この結果 は射出成形品に現れるレタデーションに大きな差がある事 からも確認された. FBPのレンズ射出成形において, 中 子への表面加工が離型性に及ぼす影響を実証的に明らかに した。すなわち，水や溶融樹脂の接触角の測定，レンズ成 形品および金型表面の観察を行った．2つの媒体を用いた 測定結果に必ずしも相関性はなく，樹脂射出成形に用いる 金型の評価には水よりも溶融樹脂を用いた接触角測定が適 切であることがあきらかになった. 2 種類の金型表面加工 材（トリアジンチオール， $\mathrm{CrN}+$ 撥水コート）において， 成形品寸法のばらつきや中子への付着の長期間抑制，連続 成形時の成形安定性確保が確認できた。更に 2 種類の金型 表面処理剤の耐久性を比較すると $\mathrm{CrN}+$ 撥水コートの方 がFBPに対しては長い効果が期待できる.

次に, FBP のレンズ射出成形品の, 単レンズ性能につ いて検証し，使用環境の影響を検証した。射出成形により 作成したレンズの焦点距離を測定したところ，計算值によ り求められる理論值をほぼ满足するレンズ成形品が得られ ていた. また, サンプル毎の焦点距離再現性も確認され, FBP は光学レンズ用材料として十分な性能を持っている ことが確認できた．高温，高湿な環境におかれた履歴を持 つFBP レンズ成形品の性能を評価したところ，試験後の サンプルは 3 種類いずれの FBP で作成したレンズ成形品 においても一定の焦点距離変動が見られた。しかしなが ら，3 種類の材料でそれぞれ変化した要因が異なることが わかった。 